\author{
Anis ur Rehman \\ Ph.D., The University of Hail, Kingdom of Saudi Arabia \\ (iD) ORCID ID: 0000-0002-9652-5201 \\ email: an.rahman@uoh.edu.sa
}

Correspondence author: an.rahman@uoh.edu.sa

\title{
INNOVATIONS IN EDUCATION MANAGEMENT: IMPACT OF EMOTIONAL INTELLIGENCE AND DEMOGRAPHIC VARIABLES ON OCCUPATIONAL STRESS AMONG UNIVERSITY TEACHERS
}

\begin{abstract}
Today emotional intelligence is increasingly relevant to the success of management as well as employees in every respect, be it internal issues like conflict resolution, group dynamics, leadership and motivation or the external issues like customer relationship management, brand loyalty and corporate social responsibility (CSR). There is limited research on the impact of emotional intelligence on job stress and workplace conduct. The objective of the article is to understand the relationship between occupational stress and emotional intelligence. It also attempts to study the impact of some demographic variables (gender, age, work experience) on occupational stress. Simple random sampling was used to collect data from teaching and non-teaching staff working in universities and educational institutions in Uttar Pradesh, India. SPSS 21 was used for data analysis using statistical tools like correlation, MannWhitney and Kruskal Wallis tests. Results show a significant relationship between emotional intelligence and occupational stress. The female employees were found to have greater stress levels as compared to their male counterparts. Age is found to have an impact on occupational stress of university teachers. The employees in their forties were found to have higher stress levels than younger employees. Work experience is also found to have an impact on occupational stress of university teachers. It was observed that employees with a work experience of more than 30 years have maximum levels of occupational stress. Based on the findings of this study, the managers should take special measures to take care of female employees and minimize factors which lead to their stress. The policies and work culture of the organization should create a conducive ambience for female employees. The organization should provide support and counselling to employees in their forties to sort out their stress-related issues which would eventually enhance their productivity. The employees with a work experience of more than 30 years (usually older ones) should get support and any stress-causing issues such as post-retirement benefits should be explained and clarified. This study adds to the current body of knowledge from a theoretical perspective. It enriches the understanding of the relationship between emotional intelligence, demographic variables and occupational stress. The top management of the organization can enhance their organization's effectiveness by learning from the findings of this study.
\end{abstract}

Keywords: Emotional Intelligence (El), occupational stress, work overload, stress management, organization.

Introduction. Emotional intelligence (EI) means the ability to understand self-feelings and that of others, ability to mould negative emotions into a positive direction and the rationale to use the emotions in a manner which is productive and qualitative. It is treated as a soft skill to smoothen the organizational working. The concept and practice of Intelligence quotient (IQ) fell inadequate to manage organizational behaviour and thus came the concept of EQ or emotional intelligence quotient. Today El is increasingly relevant to the success of management in every respect, be it internal issues like conflict resolution, group dynamics, leadership and motivation or the external issues like customer relationship management, brand loyalty and corporate social responsibility (CSR). The significant attribute of emotionally intelligent individuals is that they are 'optimistic' which enables them to focus on the solution, rather than the blame game. Figure 1 shows the different attributes of levels of Emotional intelligence. Occupational stress seems to be the biggest challenge before modern-day organizations (Belias et al., 2013; Wan et al., 2014).

Cite as: Rehman, A. (2020). Innovations in Education Management: Impact of Emotional Intelligence and Demographic Variables on Occupational Stress among University Teachers. Marketing and Management of Innovations, 3, 170-180. https://doi.org/10.21272/mmi.2020.3-12 
A. Rehman. Innovations in Education Management: Impact of Emotional Intelligence and Demographic Variables on Occupational Stress among University Teachers

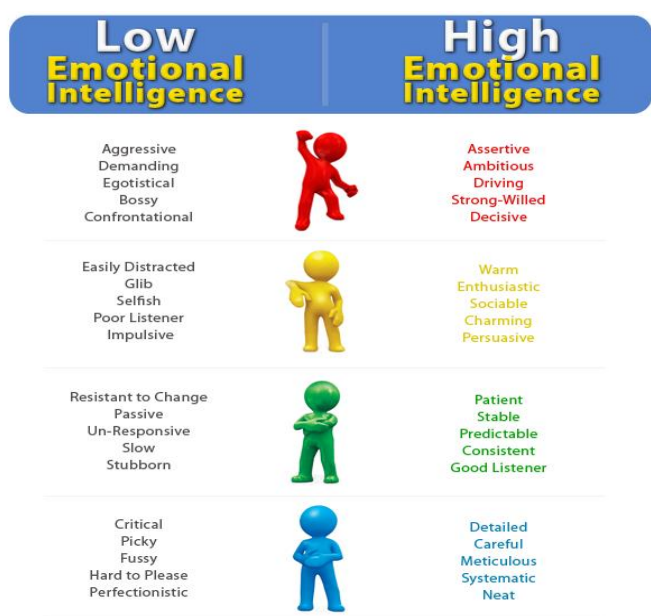

Figure 1. Attributes of Emotional intelligence levels

Source: developed by the authors based on (Zimmerman, n.d.).

Work-related stress is a cognitive and functional occurrence, which is caused as a reaction to numerous outside influences (Hellhammer and Hellhammer, 2008; Ganster and Rosen, 2013). The main reasons of work-related stress are problematic to recognize, and they span from under-developed decisions to the fright of job-loss. However, it is easy to identify the effects of job-stress on personnel as well as the organization where they work. Stress has been known to produce the advent of reduced concentration, impulsive conduct, and poor attention on employees (Burdus et al., 1996; Johns, 2011). At the organizational level, stress has been found to be the key reason for absenteeism (Johns, 2011), less production (Irawanto and Primasari, 2015), and decreased organizational loyalty (Burdus et al., 1996). To minimize these undesirable effects, the managers need to deal with the sources of stress at both individual and organizational level. The executives in modern business organizations need to develop and sustain a positive emotional culture which ensures employees' mental health and creates a well-organized work ambience (Ashkanasy, 2003). In this context, emotional intelligence (EI) is a vital means for increasing success of an organization and controlling the communication between executives and subordinates (Brackett and Salovey, 2006; Drozdowski, 2017). The managers possessing a higher level of emotional intelligence are found to be highly organized, competitive and able to use emotions to make better decisions and motivate their employees (Abraham, 2000; Watkin, 2000). In their study, Extremera, Fernandez-Berrocal, and Ramos (2007) and Belias et al. (2013) posit that employees can use El as a coping strategy to deal with stress. The previous scholars have established that the employees possessing a higher level of El prove to be highly effective in dealing with stress and are more efficient at work (Hong and Lee, 2016; O'Connor et al., 2017). Thus, employees who possess higher levels of emotional restraint and flexibility can develop several emotional mechanisms which enable them to deal with stress. Alternatively, employees having a lower level of El wish to avoid circumstances that present stress, and due to this, they may refuse important assignments which can create organizational level problems. Numerous scholars at the International level (loannis and loannis, 2002; Shukla and Srivastava, 2016) underline the association between El and occupational stress, whereas contradictory findings are also established in specific countries. According to Chinese managers, El has a constructive influence on employees' welfare and company's ambience and therefore, El is highly significant for employees, managers and organizations (Cheung et al., 2016; Li et al., 2016). There is limited research on the impact 
A. Rehman. Innovations in Education Management: Impact of Emotional Intelligence and Demographic Variables on Occupational Stress among University Teachers

of El on job stress and workplace conduct. There is also a lack of empirical studies on occupational stress in the setting of emerging economies like India. Therefore, this paper attempts to look at occupational stress concerning emotional intelligence levels and demographical characteristics of individuals.

Literature Review. Many scholars have tried to define emotional intelligence, but we can simply define emotional intelligence as the rational use of emotions (Weissinger, 1998). Thorndike's social intelligence idea has served as the basis of emotional intelligence, which attempts to comprehend and manage individuals based on their social conduct (Dogan and Demiral, 2007). In contrast, Payne (1985) was first to use the phrase emotional intelligence. The researcher defined it as an individual's ability to associate with fear, pain and desire. Salovey and Mayer (1990) are credited with one of the well-known definitions of emotional intelligence where they related it to their Four Branch Model. In this model, the ufour branches» are those elements that produce emotional intelligence: utilizing emotions, observing emotions, emotional management and social fitness (Salovey and Mayer, 1990). They described emotional intelligence as a type of social intelligence that comprises the capability to examine one's own emotions as well as others' emotions, and also the capacity to utilize these analyses to manage the actions of oneself as well as others. The "four branches» include four factors that form emotional intelligence (Salovey and Mayer, 1990): the use of emotions, perceiving emotions, emotional management and social fitness. There are numerous other definitions of emotional intelligence in addition to the definitions given by these researchers. Emotional intelligence has been defined as the capability of an individual to utilize correct perception about others as well as his own emotions, and also the capacity to enable this understanding to augment better decision-making (Martinez, 1997). Chapman (2001) adds the concept of organization's work environment when he defines emotional intelligence as the employees agreeing with company's ethics, feeling good about others and themselves, and having the urge for selling their goods.

Abraham (1999) posits that emotionally intelligent employees do not blame their organization for each feeling of frustration because they are skilled at putting themselves in optimistic states of dysfunctional emotions (Salovey and Mayer, 1990). This finding really holds true for senior-level executives who always face the problem of reuniting the feelings of frustration of contradictory interest groups inside and outside of the organization. On the ground level, people are inspired by the extent to which contents of rational exchange approach provides them with experiences like delight, exhilaration, amazement and frustration (Ashforth and Humphrey, 1995). Singh (2007) suggested that it has become vital to appreciate and leverage emotional intelligence to augment the employee capacity in organizations. Their result proposes that the personal competencies of personnel affects emotional intelligence, and the personal competency determinants of individual's accomplishment and organization's achievement have an expected association with emotional intelligence. Turner (2006) surveyed the associations between workers' emotional intelligence, their supervisor's emotional intelligence, workers' work contentment, and workers' performance from various franchise locations of the same restaurant. They found that workers' emotional intelligence was directly connected to their professional contentment and performance. Moreover, the emotional intelligence of supervisors was more directly correlated with professional contentment of subordinates with comparatively low emotional intelligence. Brown et. al (2006) has presented a model for emotional intelligence and elaborate on the skills assumed to help in precise assessment, expression and effective control of emotion in oneself and others. They further explore how the employees use their feelings for planning, motivation and achievement in their life. The modern working life is filled with change, competition, and adversities due to work overload and technological advancements, and these lead to stress for individuals. However, the concept of stress is not new. It is only recently that scholars have started to look at it scientifically, and they found that the idea of stress necessitates interdisciplinary research (Ozbay and Senyuz, 1998). The word «stress» originates from «estrica» which is a Latin verb. Even though stress referred to pain, misery and sorrow in earlier times, its meanings have evolved in recent times to pressurize and to apply force (Guney, 2000). Various researchers (Stora, 1992; Agma, 
A. Rehman. Innovations in Education Management: Impact of Emotional Intelligence and Demographic Variables on Occupational Stress among University Teachers

2007) have studied stress in numerous streams of science. Selye (1985) adopted a mental and physical viewpoint in his attempt to examine stress from the individual's reaction to any additional task or assignment given to him. He looked at stress as a mental and physical phenomenon and acknowledged stress as the struggle of a person beyond the limits of his own physical and mental capabilities due to uneasy situations arising in his surroundings. According to Schermerhorn (1989), stress can be defined as the pressure felt by a person when he/she faces unexpected situations, assignment or requests. (Rogers, 2007) defined stress as a condition which comprises of pressure, and is determined by numerous issues like experiencing change, reticence, struggle, and other distinctive individual traits. Based on various stress definitions, we can deduce that the idea of stress should not always be studied in a negative light. According to Allen (1983), the reaction of the human body to stress is similar in both negative as well as positive situations, since our body is incapable of differentiating between the impact of delightful and bitter situations. Some studies (Sahin, 2010) have intriguingly proposed that a specific amount of stress is good for individuals to remain competent and well-organized.

As suggested by Lazarus (1999), there is a strong association established between emotional intelligence and work-related stress. Lazarus found in his study that stress is dependent on emotions and both of them co-exist. Therefore, a person with high emotional intelligence can change his negative emotions into positive emotions and is more productive in a stressful environment. Thus, emotional intelligence competencies enable stress management in an organization. Kalyoncu et al. (2012) examined the association between emotional intelligence and stress in Turkish nurses working in private and government hospitals. They found that although the average emotional intelligence of female nurses was higher than male nurses, there was no substantial difference in the stress levels or emotional intelligence between the male and female nurses. They found that there was a significant connection between age and emotional intelligence and that emotional intelligence improved with an individual's age. Leon and Tanasescu (2018) surveyed the association between emotional intelligence and work-related stress in the banks of Romania. Their findings indicate that the four components of emotional intelligence display a positive effect on decreasing the level of stress, which is felt by bank employees. The employees who possessed a higher level of emotional intelligence were found to have lower stress levels because of the reason that they succeeded to comprehend and manage the emotions of others colleagues as well as their own. Furthermore, their higher emotional intelligence helped them to be more focused and resultdriven. In another research, Tanasescu and Leon (2019) studied the connections between emotional intelligence, job-related stress and worker performance in the bank employees. Their results indicated that the emotional intelligence and work-related stress of employees are negatively related, whereas the emotional intelligence and job performance are positively related to each other. Many researchers found that executives with high emotional intelligence suffer from less stress (Slaski and Cartwright, 2002; Ciarrochi et al. 2002; Gardner and Stough, 2003; Furnell, 2008; Darvish and Nasrollahi, 2011). Another study by Krishankumar and Lalita (2014) established a definite connection between work-related stress and emotional intelligence. Research by Cooper and Sawaf (1997) shows that employees with high El levels can identify the causes of stress, minimize stress and encourage a constructive work environment. Mahmood and Yadav (2017) claim that there is an insignificant relationship between emotional intelligence and occupational stress. These findings are supported by Leon and Tanasescu (2018), who surveyed the banks in Romania. They established that all four aspects of emotional intelligence (own emotions, the emotions of others, optimism and the use of emotions) have a direct effect on decreasing occupational stress felt by workers. The employees with high emotional intelligence feel less stress at the workplace because they can recognize and control their own and others' emotions. Rahim and Malik (2010) examined the impact of demographic factors (age, education, experience, gender and marital status) on El, which results in organizational performance among male and female staffs. They found that female staff is more emotionally intelligent than their male counterparts in the bank sector, and the age of 
A. Rehman. Innovations in Education Management: Impact of Emotional Intelligence and Demographic Variables on Occupational Stress among University Teachers

employees is inversely related to the level of their El. They also found that higher the education level, higher the El level of employees and vice versa. Employee contentment also determines its performance. Belias et al. (2013) found that there was a possibility of occupational stress to be affected by demographic factors like age and gender. They conclude that employees who can manage the feelings and emotions of themselves and others can effectively deal with work stress and therefore, display better job performance. Jick and Mitz (1985) claim that gender has a significant role in understanding stress. McDonald and Korabik (1991) expressed that although men and women have some common stressors, there are some exclusive stressors faced by women. Many researchers concluded that there was no significant difference in occupational stress levels of males and females (Martocchio and O'Leary, 1989; Fontana and Abouserie, 1993; Spielberger and Reheiser, 1994; Di Salvo et al. 1995). In contrast, Galanakis et al. (2009) claim that women experience higher levels of occupational stress than men. Several researchers claim that women are more susceptible to higher levels of occupational stress than men (Jick and Mitzi,1985; Ganster and Schaubroeck, 1991; Sharpley et al. 1996; Fotinatos-Ventouratos and Cooper, 2005; Antoniou et al. 2006; Mahmood and Yadav, 2017). Bolhari et al. (2012) established a significant relationship between age and organizational stress. Sager (1990) found that stress and the capability to deal with stress increases with age among people. Several researchers concluded that younger employees went through more stress than older employees in the organization (Dua, 1994; BenBakr et al. 1995; Sharpley et al. 1996). However, a different group of independent researchers claim that older employees experienced more stress as compared to younger ones (Darmordy and Smyth, 2010; Bolhari et al. 2012).

Methodology and research methods. The human mind is the concoction of various kinds of feelings resulting into a vast range of expressions ranging from stress to high morale, anger to ecstasy and liveliness to dullness; eventually affecting the productivity of the individual and that of the organization as well. Today emotional intelligence is increasingly relevant to the success of management as well as employees in every respect, be it internal issues like conflict resolution, group dynamics, leadership and motivation or the external issues like customer relationship management, brand loyalty and corporate social responsibility (CSR). Earlier studies focused on the impact of emotional stress on job stress among bank employees (Belias et al. 2003); IT sector professionals (Bolhari, 2012); real estate agents (Cheung et al. 2016); primary school teachers (Darmordy and Smyth, 2010); nurses (Kalyoncu, 2012), etc. However, studies on the impact of emotional stress on job stress among university teachers are comparatively scarce. There is also limited research on the impact of El on job stress and workplace conduct (Shah Hosseini et al., 2012). The present study is intended to focus on the association between emotional intelligence and occupational stress as well as the impact of various demographic variables on stress among university teachers. Objectives of the study. The objectives of this study are:

1. To study the relationship between occupational stress and emotional intelligence.

2. To study the impact of demographic factors like gender, age and work experience on occupational stress.

Hypothesis. The hypotheses of the study are:

$\mathrm{H} 1$ : There is no significant relationship between emotional intelligence and occupational stress.

$\mathrm{H} 2$ : There is no significant impact of gender on occupational stress of university teachers.

$\mathrm{H} 3$ : There is no significant impact of age on occupational stress of university teachers

$\mathrm{H} 4$ : There is no significant impact of work experience on occupational stress of university teachers.

Measurement instrument. Occupational Stress was measured using the Occupational Stress Index (OSI) by Srivastava and Singh (1981). This scale has 46 items which are evaluated on a Likert scale. Those items are related to the relevant stress-causing components of professional life. Herewith, they measure role conflict, role overload, role vagueness, irrational group and political pressure, powerlessness, poor peer relations, responsibility for persons, under participation, intrinsic 
A. Rehman. Innovations in Education Management: Impact of Emotional Intelligence and Demographic Variables on Occupational Stress among University Teachers

impoverishment, low status, strenuous working situations, unprofitability. Out of a total of 46 items, 28 items are true-keyed, and the remaining 18 are false-keyed. Odd-even methods were used to determine the index of split reliability of the scale which was calculated to be 0.94 . The scale reliability (Cronbach Alpha) was 0.90. Emotional intelligence of the respondents was measured with the Emotional Competence Inventory (ECl) scale developed by Boyatzis et al. (1999). The ECl measures «emotional competencies» which is associated with El. It has two forms (self-report and 360 degrees). The $\mathrm{ECl}$ has 20 competencies which are further separated into self-awareness, self-management, social awareness, and social skills. The response from employees was collected on a five-point Likert-scale. Sample and data collection. The respondents comprised of faculty members working in universities and higher education institutes in Uttar Pradesh, India. The empirical study was a descriptive cross-sectional. The cross-sectional analysis avoids several complicating facets of the use of data which is collected at different points in time. Moreover, the data analysis in cross-sectional design does not require an assumption that the variables have a stable relationship among themselves over time. An online questionnaire developed through Google Docs application was sent to respondents through e-mail and social media channels. This method has been successfully used in previous studies (Bian and Forsythe, 2012; Rehman, 2017; Rehman, 2020). The questionnaires were distributed to 485 respondents using simple random sampling. In turn, 237 valid responses were received. The data collection was from December 2019 to March 2020. The data was entered in SPSS version 21 to obtain results. Correlation, Mann-Whitney and Kruskal Wallis tests were the statistical tools used for the analysis of data.

Results. A brief profile of the sample is summarised in Table 1.

Table 1. Sample Profile

\begin{tabular}{|c|c|c|c|c|c|c|c|}
\hline \multicolumn{2}{|c|}{ Demography } & $\mathbf{N}$ & $\%$ & \multicolumn{2}{|c|}{ Demography } & $\mathbf{N}$ & $\%$ \\
\hline \multirow{3}{*}{ Gender } & Male & 132 & $55.7 \%$ & \multirow{8}{*}{$\begin{array}{c}\text { Work } \\
\text { experie } \\
\text { nce }\end{array}$} & Less than 5 & 68 & $28.69 \%$ \\
\hline & Female & 105 & $44.3 \%$ & & $5-10$ & 83 & $35.02 \%$ \\
\hline & Total & 237 & $100 \%$ & & $11-20$ & 37 & $15.61 \%$ \\
\hline \multirow{5}{*}{ Age } & Less than 30 & 62 & $26.16 \%$ & & $21-30$ & 29 & $12.24 \%$ \\
\hline & $30-39$ & 90 & $37.97 \%$ & & More than 30 & 20 & $8.44 \%$ \\
\hline & $40-49$ & 63 & $26.58 \%$ & & \multirow{3}{*}{ Total } & \multirow{3}{*}{237} & \multirow{3}{*}{$100 \%$} \\
\hline & More than 50 & 22 & $9.28 \%$ & & & & \\
\hline & Total & 237 & $100 \%$ & & & & \\
\hline
\end{tabular}

For testing H01, a Spearman's correlation was run to establish the relationship between Occupational Stress and Emotional Intelligence. As shown in Table 2, the p-value for this test is 0.002 . Therefore, there is very strong evidence to reject $\mathrm{H} 01$, i.e. evidence to believe that occupational stress and emotional intelligence are correlated in the population. Therefore, a moderate, negative correlation has been found among occupational stress and emotional intelligence ( $r s=-0.418, n=237, p<0.001)$. Thus, hypothesis $\mathrm{H} 01$ is rejected.

Table 2. Correlation between Occupational Stress and Emotional Intelligence

\begin{tabular}{|l|c|}
\hline Spearman's Rho & -0.418 \\
\hline Sig & 0.002 \\
\hline $\mathbf{N}$ & 237 \\
\hline
\end{tabular}

Source: developed by the authors based on SPSS output.

Then, the relationship between occupational stress and the demographic variables of gender, age and work experience were studied. For testing the second null-hypothesis H02, a Mann-Whitney's U test was performed (Table 3 and Table 4). 
A. Rehman. Innovations in Education Management: Impact of Emotional Intelligence and Demographic Variables on Occupational Stress among University Teachers

Table 3. Ranking of Respondents according to Gender

\begin{tabular}{|l|l|l|l|}
\hline Gender & N & Mean Rank & Sum of Ranks \\
\hline Male & 132 & 158.48 & $20,919.36$ \\
\hline Female & 105 & 79.20 & 8,316 \\
\hline
\end{tabular}

Source: developed by the authors based on SPSS output.

Table 4. Relationship between Gender and Occupational Stress

\begin{tabular}{|l|c|}
\hline Test & Output \\
\hline Mann-Whitney U & 3,256 \\
\hline Wilicoxon W & 8,316 \\
\hline Z & -1.136 \\
\hline Asymp. Sig. (2-tailed) & 0.032 \\
\hline
\end{tabular}

Source: developed by the authors based on SPSS output.

As seen in Table 3, 4, the p-value for this test is 0.032 . Therefore, it is possible to reject hypothesis H02. The rank of females (79.20) was higher than males (158.48). Besides, the occupational stress levels among females were more as compared to their male colleagues. It concludes that the data provides statistical evidence of the significant impact of gender on occupational stress of university teachers (Mann Whitney $U=3256, z=-1.136, p=0.032$ ).

The effect of age and work experience on occupational stress was tested using the Kruskal Wallis test (since both variables have more than two groups within themselves). Table 5 shows that the $p$-value (Asymp. Sig. 2-tailed) is less than 0.05 for both age and experience.

Table 5. Relationship between Age, Experience and Occupational Stress

\begin{tabular}{|l|l|l|l|}
\hline Occupational Stress & Variable & Asymp. Sig. (2-tailed) & Chi-Square \\
\hline & Age & 0.021 & 17.78 \\
\cline { 2 - 4 } & Experience & 0.001 & 53.12 \\
\hline
\end{tabular}

Source: developed by the authors based on SPSS output.

Therefore, we have to reject the null hypotheses $\mathrm{H} 03$ and $\mathrm{H} 04$. Thus, we have statistical evidence to believe that there is a significant impact of age on occupational stress of university teachers $(X 2=17.78$, $p=0.021$ ). Similarly, we have statistical evidence to believe that work experience has a significant impact on occupational stress of university teachers $(X 2=53.12, p=0.001)$. According to the current study, there is a significant negative correlation between emotional intelligence and occupational stress among employees working in universities and educational institutions. It implies that high emotional intelligence in these employees results in lower occupational stress and vice versa. This finding is supported by the work of other researchers who reported a negative relationship between emotional intelligence and jobrelated stress (Slaski and Cartwright, 2002; Ciarrochi et al. 2002; Gardner and Stough, 2003; Furnell, 2008; Darvish and Nasrollahi, 2011). Female employees had higher occupational stress levels than male employees. The reason could be because of their more responsibility for the family, and the extra effort to balance family and professional life might lead to their higher job stress. This finding is supported by numerous studies worldwide who found higher occupational stress level in female employees (Jick and Mitzi,1985; Ganster and Schaubroeck, 1991; Sharpley et al. 1996; Fotinatos-Ventouratos and Cooper, 2005; Antoniou et al. 2006; Galanakis et al. 2009; Mahmood and Yadav, 2017).

The results showed that age had an impact on occupational stress of university teachers. The employees in their forties had higher stress levels than younger employees which are also supported by the findings of Darmordy and Smyth (2010). Besides, work experience had an impact on occupational 
A. Rehman. Innovations in Education Management: Impact of Emotional Intelligence and Demographic Variables on Occupational Stress among University Teachers

stress of university teachers. It was observed that employees with a work experience of more than 30 years have maximum levels of occupational stress.

Conclusions. This paper attempted to explore and measure the association between occupational stress and emotional intelligence. There is limited research on the impact of El on job stress and workplace conduct (Shah Hosseini et al., 2012). There is also a lack of empirical studies on occupational stress in the setting of emerging economies like India. The findings of this study suggest that there exists a negative correlation between emotional intelligence and job-related stress. Moreover, the stress level of female employees is higher in comparison to male employees. Age and work experience has a significant impact on occupational stress levels. This paper adds to the existing literature on occupational stress and emotional intelligence from a theoretical perspective. It enriches the understanding of the relationship between emotional intelligence, demographic variables and occupational stress. However, the results of this study could not be generalized in the context of employees from other organizational sectors and countries. Further studies would be required in different sectors and countries to validate the results of this study. The top management of the organization can enhance their organization's effectiveness by learning from the findings of this study. Managers should take special measures to take care of female employees and minimize factors which lead to their stress. The policies and work culture of the organization should create a conducive ambience for female employees. The organization should provide support and counselling to employees in their forties to sort out their stress related issues which would eventually enhance their productivity. The employees with a work experience of more than 30 years (usually older ones) should get support and any stress-causing issues such as post-retirement benefits should be explained and clarified. This study had its limitations. The linkage between components should be analyzed with caution due to the cross-sectional nature of the study. The measurement of El has always been complicated and problematic. There is no consensus over the issue of whether El can be taught.

There is a need to carry out related studies on employees of various other professions across India to get a clear picture. There is also a need to study the impact of other demographic variables (like educational qualification, annual income, and designation level in the organization) on occupational stress. The impact of various demographic variables on emotional intelligence should also be explored.

Funding. This research received no external funding.

\section{References}

Abraham, R. (1999). Emotional Intelligence in Organizations: a Conceptualization. Genetic Social and General Psychology Monographs, 125(2), 209-224. [Google Scholar]

Abraham, R. (2000). The role of job control as a moderator of emotional dissonance and emotional intelligence outcome relationships. Journal of Psychology, 134(2), 169-184. [Google Scholar] [CrossRef]

Agma, F. S. (2007). The negative effects and reasons of stress in work life. Master's thesis, Atılım University, Ankara, Turkey. [Google Scholar]

Allen, R. J. (1983). Human stress: Its nature and control. Burgess. [Google Scholar]

Antoniou, A. S., Polychroni, F., \& Vlachakis, A. N. (2006). Gender and age differences in occupational stress and professional burnout between primary and high-school teachers in Greece. Journal of Managerial Psychology, 21(7), 682-690. [Google Scholar] [CrossRef]

Ashforth, B. E., \& Humphrey, R. H. (1995). Emotion in the workplace: A reappraisal. Human Relations, 48(2), 97-99. [Google Scholar] [CrossRef]

Ashkanasy, N. M. (2003). Emotions in organizations: A multi-level perspective. In Dansereau, F., and Yammarino, F.J. (Eds.) Multi-Level Issues in Organizational Behavior and Strategy (pp.9-54). Oxford, UK: Elsevier. [Google Scholar] [CrossRef]

Belias, D., Koustelios, E., Koutiva, M., \& Zournatzi, E. (2013). Occupational stress and emotional intelligence among Greek Bank employees. International Journal of Human Resource Studies, 3(4), 79-101. [Google Scholar] [CrossRef]

Ben-Bakr, K. A., Al-Shammari, I. S., \& Jefri, O. A. (1995). Occupational stress in different organizations: a Saudi Arabian survey. Journal of Managerial Psychology, 10(5), 24-28. [Google Scholar] 
A. Rehman. Innovations in Education Management: Impact of Emotional Intelligence and Demographic Variables on Occupational Stress among University Teachers

Bian, Q., \& Forsythe, S. (2012). Purchase intention for luxury brands: A cross cultural comparison. Journal of Business Research, 65(10), 1443-1451.

Bolhari, A., Rezaeian A., Bolhari, J., \& Bairamzadeh, S. (2012). Occupational Stress Level among Information Technology Professionals in Iran. International Journal of Information and Electronics Engineering, 2(5). [Google Scholar]

Boyatzis, R. E., Goleman, D., \& Rhee, K. (1999). Clustering competence in emotional intelligence: Insights from the Emotional Competence Inventory (ECI). In R. Bar-On \& J.D. Parker (Eds.), Handbook of Emotional Intelligence. San Francisco: Jossey-Bass. [Google Scholar]

Brackett, M. A., \& Salovey, P. (2006). Measuring emotional intelligence with the Mayer-Salovery-Caruso emotional intelligence test (MSCEIT). Psicothema, 18, 34-41. [Google Scholar]

Brown, F. W., Bryant, S. E., \& Reilly, M. D. (2006). Does emotional intelligence - as measured by the EQI - influence transformational leadership and/or desirable outcomes? Leadership \& Organisation Development Journal, 27(5), 330 - 351. [Google Scholar] [CrossRef]

Burdus, E., Caprarescu, G., \& Zorlențan, T. (1996). Organisational management [Managementul organizației]. Bucharest: Holding Reporter. [Google Scholar]

Chapman, M. (2001). The Emotional Intelligence Pocketbook. Management Pocketbooks, Arlesford. [Google Scholar]

Cheung, S. Y., Gong, Y. P., \& Huang, J. C. (2016). Emotional intelligence, job insecurity, and psychological strain among real estate agents: a test of madiation and moderation models. International Journal of Human Resource Management, 27(22), 26732694. [Google Scholar]

Ciarrochi, J., Deane, F. P., \& Anderson, S. (2002). Emotional intelligence moderates the relationship between stress and mental health. Personality and Individual Differences, 32 (2), 197-209. [Google Scholar]

Cooper, R. K., \& Sawaf, A. (1997). Executive EQ: emotional intelligence in leadership and organizations. New York: Grosset Putnum. [Google Scholar]

Darmordy, M., \& Smyth, E. (2010). Job Satisfaction and Occupational Stress among Primary School Teachers and School Principals in Ireland. Ireland: The Teaching Council. [Google Scholar]

Darvish, H., \& Nasrollahi, A. A. (2011). Studying the relations between emotional intelligence and occupational stress: A case study at Payame Noor University. Economic Sciences Series, 2(18), 38-49. [Google Scholar]

Di Salvo, V., Lubbers, C., Rossi, A. M., \& Lewis, J. (1995). Unstructured perceptions of work-related stress: An exploratory qualitative study. In: R Crandall, P.L. Perrewe (Eds). Occupational Stress: A Handbook (pp.39-50). Washington: Taylor Francis [Google Scholar]

Dogan, S., \& Demiral, O. (2007). The role and importance of emotional intelligence on the success of organizations. Celal Bayar University the Faculty of Economic and Administrative Sciences Journal, 14(1), 209-230. [Google Scholar]

Drozdowski, G. (2017). Emotional components of competence among executives: An empirical study. Economic Annals-XXI,

162(11/12), 89-92. [Google Scholar]

Dua, J. K. (1994). Job stressors and their effects on physical health, emotional health, and job satisfaction in a university. Journal of Educational Administration, 32, 59-78. [Google Scholar]

Extremera, N., Fernandez-Berrocal, P., \& Ramos, N. S. (2007). Perceived emotional intelligence facilitates cognitive emotional processes of adaptation to an acute stressor. Cognition \& Emotion, 21(4), 758-772. [Google Scholar]

Fontana, D., \& Abouserie, R. (1993). Stress levels gender and personality factors in teachers. British Journal of Educational Psychology, 63(1), 261-270. [Google Scholar]

Fotinatos-Ventouratos, R., \& Cooper, C. (2005). The role of gender and social class in work stress. Journal of Managerial Psychology, 20(1), 14-23. [Google Scholar]

Friedman, M. (1996). Type A Behavior: Its Diagnosis and Treatment. New York, Plenum Press (Kluwer Academic Press), 31 [Google Scholar]

Furnell, B. A. (2008). Exploring the relationship between burnout, emotional labour and emotional intelligence: a study on call centre representatives. Master Dissertation in Psychology, Stellenbosch: Department of Industrial Psychology, University of Stellenbosch. [Google Scholar]

Galanaki, M., Stalikas, A., Kallia, H., Karagianni, C., \& Karela, C. (2009). Gender differences in experiencing occupational stress: the role of age, education and marital status. Stress and Health, 25(5), 397-404. [Google Scholar]

Ganster, D. C., \& Rosen, C. C. (2013). Work stress and employee health: A multidisciplinary review. Journal of Management, 39(5), 1085-1122. [Google Scholar]

Ganster, D. C., \& Schaubroeck, J. (1991). Work Stress and Employee Health. Journal of Management, 17(2), 235-271. [Google Scholar]

Gardner L. J., \& Stough, C. (2003). Exploration of the relationship between workplace, emotional intelligence, occupational stress and employee health. Australian Journal of Psychology, 55(1), 181-95. [Google Scholar]

Guney, S. (2000). Behavioural sciences. Nobel Publications, Ankara Turkey.

Hellhammer, D. H., \& Hellhammer, J. (2008). Stress: The brain-body connection (Key issues in mental health). New York, NY: Karger. [Google Scholar]

Hong, E., \& Lee, Y. S. (2016). The mediating effect of emotional intelligence between emotional labour, job stress, burnout and nurses' turnover intention. International Journal of Nursing Practice, 22(6), 625-632. [Google Scholar] [CrossRef] 
A. Rehman. Innovations in Education Management: Impact of Emotional Intelligence and Demographic Variables on Occupational Stress among University Teachers

Hughes, M. L., Patterson, B. \& Bradford, T. J. (2005). Emotional intelligence in action. Wiley. [Google Scholar]

loannis, N., \& loannis, T. (2002). Emotional intelligence in the workplace: exploring its effects on occupational stress and organizational commitment. International Journal of Organisational Analysis, 10(4), 327-342. [Google Scholar] [CrossRef] Irawanto, D. W., \& Primasari, N. D. (2015). The Effect of Occupational Stress on Work Performance of Female Employees: Study in Indonesia. Asia-Pacific Journal of Management Research and Innovation, 11(4), 336-345. [Google Scholar] [CrossRef] Jick, T. D., \& Mitz, L. F. (1985). Sex differences in work stress. Academy of Management review, 10(1), 408-420. [Google Scholar][CrossRef]

Johns, G. (2011). Attendance dynamics at work: The antecedents and correlates of presenteeism, absenteeism, and productivity loss. Journal of Occupational Health Psychology, 16(4), 483-500. [Google Scholar] [CrossRef]

Kalyoncu, Z., Guney, S., Arslan, M., \& Ayranci, E. (2012). Analysis of The Relationship Between Emotional Intelligence and Stres Caused by The Organisation: A Study of Nurses. [Google Scholar]

Krishankumar, R., \& Lalitha, S. (2014). A Study on Emotional Intelligence and Occupational Stress. International Journal of Multidisciplinary and Current Research, 2(2), 633-36. [Google Scholar]

Lazarus, R. S. (1999). Stress and emotions: A new synthesis. New York, NY: Springer Publishing Company. [Google Scholar] Leon, R. D., \& Tanasescu, R. I. (2018). Emotional Intelligence and Occupational Stress in Romanian Organizations. Management Dynamics in the Knowledge Economy, 6(1), 51-65. [Google Scholar]

Li, Z. D., Gupta, B., Loon, M., \& Casimir, G. (2016). Combinative aspects of leadership style and emotional intelligence. Leadership \& Organisation Development Journal, 37(1), 107-125. [Google Scholar] [CrossRef]

Mahmood, A., \& Yadav, L. K. (2017). Occupational Stress, Emotional Intelligence and Demography: A study among working professionals. International Journal of Business Insights and Transformation, 10 (2), 72-79. [Google Scholar] Martinez, M. N. (1997). The smarts that count. HR Magazine, 42 (11): 72-78. [Google Scholar]

Martocchio, J. J., \& O'Leary, A. M. (1989). Sex differences in occupational stress: A meta-analytic review. Journal of Applied Psychology, 74, 495-501. [Google Scholar] [CrossRef McClelland, D. (1998). Identifying competencies with behavioural-event interviews. Psychol. Sci., 9(5), 331-40. [Google Scholar] [CrossRef]

McDonald, L. M., \& Korabik, K. (1991). Sources of stress and ways of coping among male and female managers. Journal of Social Behaviour and Personality, 6(1), 185-198. [Google Scholar]

O'Connor, P., Nguyen, J., \& Anglim, J. (2017). Effectively Coping with Task Stress: A Study of the Validity of the Trait Emotional Intelligence Questionnaire- Short Form (TEIQue-SF). Journal of Personality Assessment, 99(3), 304-314. [Google Scholar] [CrossRef]

Ozbay, Y., \& Senyuz, A. (1998). An analysis of perceived job satisfaction in different occupations and stress levels in relation to gender. Paper presented at The Tenth National Psychology Congress, $16-18$ September 1998, Ankara, Turkey.

Payne, W. L. (1985). A Study of Emotion: Developing Emotional Intelligence; Self-Integration; Relating to Fear, Pain and Desire (Theory, Structure of Reality, Problem-Solving, Contraction/Expansion, Tuning In/Coming Out/Letting Go). Doctoral dissertation, The Union for Experimenting Colleges and Universities (The Union Institute), Cincinnati, $\mathrm{OH}$. [Google Scholar] Rahim, S. H., \& Malik, M. I. (2010). Emotional Intelligence \& Organizational Performance: A Case Study of Banking Sector in Pakistan. International Journal of Business and Management, 5(10), 191-197. [Google Scholar]

Rehman, A. (2020). Innovation and Management by Regional Rural Banks in Achieving the Dream of Financial Inclusion in India: Challenges and Prospects.

Rehman, A. U. (2017). Green values and buying behaviour of consumers in Saudi Arabia: an empirical study. International Journal of Green Economics, 11(2), 154-164.

Rogers, A. K. (2007). Stress Perceptions in Occupational Therapy Students: Traditional versus Distance Education. Master's thesis, West Virginia University, Morgantown, WV. [Google Scholar] Sager, J. K. (1990). Reducing sales manager job stress. The Journal of Consumer Marketing, 7(4), 5-14. [Google Scholar] [CrossRef

Sahin, N. H. (2010). Finding your own «positive stress» level, coping up with stress: A positive approach. Turkish Psychologists Association Publications, Ankara, Turkey.

Salovey, P., \& Mayer, J. D. (1990). Emotional intelligence. Imagination, Cognition, and Personality, 9, 185-211. [Google Scholar] [CrossRef]

Schermerhorn, J. R. (1989). Management for Productivity. John Wiley and Sons Inc., New York. [Google Scholar] Seipp, B. (1991). Anxiety and academic performance: A meta-analysis of findings. Anxiety Res., 4, 27-41. [Google Scholar] [CrossRef]

Selye, H. (1985). The Stress of Life. Springer-Verlag, New York. [Google Scholar]

Shah Hosseini, M., Silong, A. D., Ismaili, I. A., \& Uli, J. N. (2012). The role of emotional intelligence on job performance. International Journal of Social Science, 3(21), 241-246. [Google Scholar]

Sharpley, C. F., Reynolds, R., Acosta, A., \& Dua, J. K. (1996). The presence, nature and effects of job stress on physical and psychological health at a large Australian university. Journal of Educational Administration, 34(4), 73-86. [Google Scholar] [CrossRef] Shukla, A., \& Srivastava, R. (2016). Examining the effect of emotional intelligence on socio-demographic variable and job stress among retail employees. Cogent Business \& Management, 3(1), 1201905. [Google Scholar] [CrossRef]

http://mmi.fem.sumdu.edu.ua/en 
A. Rehman. Innovations in Education Management: Impact of Emotional Intelligence and Demographic Variables on Occupational Stress among University Teachers

Singh, K. (2007). Quantitative social research methods. Thousand Oaks, CA: SAGE publications. [Google Scholar]

Slaski, M., \& Cartwright, S. (2002). Health, performance and emotional intelligence: An exploratory study of retail managers. Stress Health, 18(1), 63-8. [Google Scholar]

Spielberger, C. D., \& Reheiser, E. C. (1994). The job stress survey: Measuring gender differences in occupational stress. Journal of Social Behaviour and Personality, 9(1), 199-218. [Google Scholar]

Srivastava, A. K., \& Singh, A. P. (1981). Manual of the Occupational Stress Index, Department of Psychology, Banaras Hindu University, Varanasi. [Google Scholar]

Stora, J. B. (1992). Stress. Trans. by Ayse Kalın, Iletisim Publications, Istanbul, Turkey.

Tanasescu, R. I., \& Leon, R. D. (2019). Emotional Intelligence, Occupational Stress and Job Performance in the Romanian Banking System: A Case Study Approach. Management Dynamics in the Knowledge Economy, 7(3), 323-335. [Google Scholar]

Turner, T.W. (2006). Identifying emotional intelligence competencies differentiating FBI National Academy graduates from other law enforcement leaders. Ed. D. University of Virginia, United States - Virginia. [Google Scholar]

Wan, H. C., Downey, L. A., \& Stough, C. (2014). Understanding non-work presenteeism: Relationships between emotional intelligence, boredom, procrastination and job stress. Personality and Individual Differences, 65(1), 86-90. [Google Scholar] [CrossRef]

Watkin, C. (2000). Developing emotional intelligence. International Journal of Selection and Assessment, 8(2), 89-92. [Google Scholar] [CrossRef

Weissinger H (1998). Emotional intelligence at work life. Trans. by Nurettin Suleymangil. MNS Publications, Istanbul, Turkey. [Google Scholar]

Zimmerman, A. (n.d.) What is emotional intelligence? Retrieved from https://www.trans4mind.com/heart/eq.html

\section{Анис Р. Рахман, Ph.D., Державний університет в Хаіль, Саудівська Аравія}

Інновації в управлінні освітою: вплив емоційного інтелекту та демограсфічних фракторів на рівень стресостійкості викладачів університету

у статті висвітлено особливості управління емоційним інтелектом у сучасних ринкових умовах. Автором визначено вплив емоційного інтелекту на швидкість та ефективність вирішення внутрішніх (конфрлікти, психологічна поведінка в колективі, лідерство та мотивація) та зовнішніх проблем організації (управління взаємовідносинами із клієнтами, лояльність до бренду, корпоративна соціальна відповідальність). Головною метою cmammi є визначення взаємозв'язку між рівнем професійного стресу та емоційним інтелектом, а також оцінювання впливу демографрічних змінних (вік, стать, досвід роботи) на рівень просесійного стресу. Вихідні данні для дослідження сформовано на основі простої випадкової вибірки педагогічного персоналу та інших працівників навчальних закладів штату Уттар-Прадеш, Індія. Практичну реалізацію усіх етапів дослідження здійснено 3 використанням програмного забезпечення SPSS 21. Методологію дослідження засновано на статистичних методах кореляиії, U-критерію Манна-Уітні та тесту Крускала-Уолліса. Отримані результати свідчать про статистично значущу залежність між емоційним інтелектом та рівнем стресостійкості на роботі. Встановлено, що рівень сприйняття стресу залежить від статі, віку та професійного стажу. Автор відмітив, що у жінок та працівників старше сорока років, рівень чутливість до стресу на роботі є вищим. Встановлено, що працівники з професійним стажем понад тридиять років мають найвищий рівень чутливості до просресійного стресу. У зв'язку з цим, у статті зазначено, що з метою мінімізації тригерів стресу серед жінок, керівництву необхідно забезпечити сприятливі умови праці та позитивний психологічний клімат. Враховуючи отримані результати, автором доведено необхідність забезпечення психологічної підтримки працівників старше сорока років та зі стажем понад тридиять років з метою зниження рівня стресу, а також підвищення рівня продуктивності праці. Результати дослідження збагачують теоретичні напрацювання щодо дослідження взаємозв'язку між емоційним інтелектом, демографрічними змінними та рівнем професійного стресу. Крім цього, результати дослідження можуть бути корисними керівництву організацій при розробленні стратегії підвищення ефективності діяльності організаиії.

Ключові слова: емоційний інтелект (ЕІ), професійний стрес, робоче перевантаження, управління стресом, організація.

Manuscript received: 06.05.2020

(C) The author(s) 2020. This article is published with open access at Sumy State University 